\title{
Penerapan Concept Mapping dengan Media Gambar untuk Meningkatkan Kualitas Pembelajaran IPA
}

\author{
Siti Lathifah Rahmawati, Sri Hartati, Atip Nurharini \\ Jurusan Pendidikan Guru Sekolah Dasar \\ Fakultas Ilmu Pendidikan \\ Universitas Negeri Semarang \\ Email: lathifahslr@yahoo.com
}

\begin{abstract}
Abstrak
Tujuan penelitian ini adalah meningkatkan kualitas pembelajaran IPA melalui concept mapping dengan media gambar pada siswa kelas VB SDN Sampangan 01 Semarang.Penelitian ini merupakan penelitian tindakan kelas terdiri dari tiga siklus.Subyek penelitian ini adalah guru dan siswa kelas VB SDN Sampangan 01 Semarang.Teknik pengumpulan data yang digunakan adalah teknik nontes dantes.Analisis data menggunakan data kuantitatif dan data kualitatif. Hasil penelitian menunjukkan peningkatan dalam setiap variabel dalam setiap siklusnya, setiap siklus terdirisatu pertemuan. Tingkat pencapaian keterampilan guru di siklus I adalah 55\% dengan kategori cukup, siklus II sebesar 73\%dengan kategori baik, dan siklus III sebesar 93\% dengan kategori sangat baik. Tingkat pencapaian aktivitas siswa di siklus I adalah $45,45 \%$ dengan kategori cukup, siklus II sebesar $71,97 \%$ dengankategori baik, dan siklus III sebesar 81,36\% dengan kategori sangat baik. Tingkat pencapaian hasil belajar siswa di siklus I adalah 57,57\%, siklus II sebesar 78,78\%, dan siklus III sebesar 96,96\%. Apabila dikaitkan dengan nilai KKM SDN Sampangan 01 Semarang sebesar 62, maka nilai rata-rata siklus I, II, dan III sudah mencapai KKM. Sedangkan perolehan ketuntasan klasikal yang mencapai indikator keberhasilan $\geq 80 \%$ terpenuhi pada siklus III. Simpulan penelitian ini yaitu concept mapping dengan media gambar dapat meningkatkan kualitas pembelajaran IPA kelasVB SDN Sampangan 01 Semarang.
\end{abstract}

Kata kunci: concept mapping;gambar; kualitas pembelajaran IPA

\section{PENDAHULUAN}

Pendidikan IPA diharapkan dapat menjadi wahana bagi peserta didik untuk mempelajari diri sendiri dan alam sekitar, serta prospek pengembangan lebih lanjut dalam menerapkannya di dalam kehidupan sehari-hari. Proses pembelajarannya menekankan pada pemberian pengalaman langsung untuk mengembangkan kompetensi agar menjelajahi dan memahami alam sekitar secara ilmiah. Pendidikan IPA diarahkan untuk inkuiri dan berbuat sehingga dapat membantu peserta didik untuk memperoleh pemahaman yang lebih mendalam tentang alam sekitar (BSNP, 2006).

Peneliti bersama tim kolaborator melakukan refleksi melalui observasi sehingga ditemukan masalah mengenai kualitas pembelajaran IPA yang masih rendah. Dari data yang diperoleh ditemukan beberapa masalah di antaranya guru kurang dapat menjelaskan hubungan antar konsep dari materi pelajaran yang diberikan kepada siswa. Guru juga belum mengajak siswa untuk saling berbagi pemahaman yang dimiliki. Selain itu, guru merasa semua tanggung jawab dalam pembelajaran ada pada dirinya. Pada akhirnya semua hal tersebut berakibat siswa kesulitan dalam mengaitkan hubungan antar konsep dari materi pelajaran yang diberikan oleh guru. Siswa juga kurang dapat berbagi mengenai 
pemahaman yang dimilikinya. Selain itu, siswa kurang diberi kesempatan untuk ikut berperan aktif dalam pembelajaran. Permasalahan tersebut juga didukung dengan perolehan hasil belajar siswa kelas VB SDN Sampangan 01 Semarang pada mata pelajaran IPA semester 1 yang belum optimal. Dengan jumlah siswa kelas VB SDN Sampangan 01 Semarang berjumlah 33 siswa, hanya 12 siswa (36\%) yang dapat lulus melampaui KKM yang telah ditetapkan yakni 62 dan sisanya 21 siswa (64\%), tidak dapat menjangkau KKM yang telah ditetapkan. Dari data yang diperoleh tersebut makaperlu sekali dilaksanakan kegiatan pembelajaran yang inovatif untuk meningkatkan kualitas pembelajaran IPA.

Untuk memecahkan masalah pembelajaran tersebut, maka dilakukan penelitian tindakan kelas melalui conceptmapping dengan media gambar. Sehingga rumusan masalah dalam penelitian ini adalah: Bagaimanakah cara meningkatkan kualitas pembelajaran IPA pada siswa kelas VB SDN Sampangan 01 Semarang?

Penelitian tindakan kelas dilakukan dengan menggunakan strategi concept mapping dengan media gambar. Concept mapping dikembangkan untuk mengetahui seberapa dalam pengetahuan yang telah dimiliki oleh siswa. Concept mapping menurut Dahar (2011) merupakan suatu pendekatan yang dapat dilaksanakan dan dikembangkan baik oleh pelajar atau guru secara sadar dan bebas. Kelebihan pembelajaran dengan menggunakan concept mapping menurut Munthe (2014) diantaranya: 1) berbagi pemahaman baik dari guru maupun dari siswa; 2) mengaitkan hubungan antar konsep secara runtut; 3) mengaktifkan siswa. Sedangkan media yang digunakan adalah media visual yang berupa gambar. Gambar ini dapat berupa sketsa, lukisan, dan photo. Photo merupakan gambar hasil pemotretan atau photografi. Photo dapat memvisualisasikan objek dengan lebih konkret dan dapat mengatasi ruang dan waktu.

Tujuan penelitian ini adalah untuk meningkatkan kualitas pembelajaran IPA melaluiconcept mapping dengan media gambarpada siswa kelas VB SDN Sampangan 01 Semarang.

\section{METODE PENELITIAN}

Subjek dalam penelitian ini adalah guru dan siswa kelas VB SDN Sampangan 01 Semarang dengan jumlah siswa 21 laki-laki dan 13 perempuan. Variabel penelitiannya yaitu keterampilan guru, aktivitas siswa, dan hasil belajar siswa dalam kegaiatan pembelajaran IPA menggunakan conceptmapping dengan media gambar di kelas VB SDN Sampangan 01 Semarang. Penelitian tindakan kelas ini dilaksanakan dalam tiga siklus, setiap siklus satu kali pertemuan dengan empat tahapan yaitu perencanaan, pelaksanaan, observasi, dan refleksi (Arikunto, 2008). Teknik pengumpulan data menggunakan nontes dan tes. Sedangkan teknik analisis data menggunakan teknik analisis data kuantitatif dan kualitatif. Teknik analisis data kuantitatif berupa hasil belajar dianalisis dengan teknik analisis statistik deskriptif dengan menentukan mean. Teknik analisis data kualitatif berupa data hasil 
observasi keterampilan guru dan aktivitas siswa. Adapun penyajian teknik analisis data tersebut adalah sebagai berikut:

\section{Data Kuantitatif}

Skor $=($ skala $0-100)$

Ket: $B=$ banyaknya butir soal yang dijawab benar, $N=$ banyaknya butir soal

Rumus tersebut digunakan untuk menganalisis data hasil belajar siswa (Poerwanti, 2008).

$\mathrm{x}=\frac{\sum X}{\sum N}$

Ket: $\mathrm{x}=$ nilai rata-rata, $\sum X=$ jumlah semua nilai siswa, $\sum N=$ jumlah siswa

Rumus tersebut digunakan untuk menghitung nilai rata-rata kelas (Aqib, 2011).

$\rho=\frac{\sum \text { siswa yang tuntas belajar }}{\sum \text { siswa }} \times 100 \%$

Keterangan $: \rho=$ persentase

Rumus tersebut digunakan untuk menghitung persentase ketuntasan belajar klasikal (Aqib, 2011).

\section{Data Kualitatif}

$\mathrm{n}=(\mathrm{M}-\mathrm{K})+1$

Ket: $\mathrm{M}=$ skor maksimal, $\mathrm{K}=$ skor minimal, $\mathrm{n}$ = banyaknya data

Rumus tersebut digunakan untuk menghitung letak kuartil dalam pembuatan kriteria penilaian terhadap keterampilan guru dan aktivitas siswa (Herrhyanto, 2008).

\section{HASIL DAN PEMBAHASAN}

\section{Keterampilan Guru}

Peningkatan keterampilan guru dalam pembelajaran IPA dapat dilihat pada tabel berikut:

Tabel 1 Peningkatan Keterampilan Guru pada Siklus I, Siklus II, dan Siklus III

\begin{tabular}{|c|l|c|c|c|}
\hline No. & \multicolumn{1}{|c|}{ Indikator } & Siklus I & Siklus II & Siklus III \\
\hline 1. & Melakukan pengkondisian awal kelas & 4 & 4 & 4 \\
\hline 2. & Membuka pelajaran & 2 & 2 & 4 \\
\hline 3. & Menyampaikan materi pelajaran & 2 & 3 & 4 \\
\hline 4. & Mengajukan pertanyaan kepada siswa & 2 & 3 & 4 \\
\hline 5. & $\begin{array}{l}\text { Memberikan LKS berupa crossword } \\
\text { puzzle }\end{array}$ & 2 & 3 & 4 \\
\hline 6. & $\begin{array}{l}\text { Memberi penguatan kepada kelompok } \\
\text { yang menyelesaikan tugas dengan benar }\end{array}$ & 3 & 3 & 4 \\
\hline 7. & $\begin{array}{l}\text { Membimbing dalam pembuatan concept } \\
\text { mapping }\end{array}$ & 2 & 3 & 4 \\
\hline 8. & Membimbing siswa dalam kelompok & 2 & 3 & 4 \\
\hline 9. & $\begin{array}{l}\text { Membimbing siswa menyimpulkan } \\
\text { materi }\end{array}$ & 1 & 1 & 2 \\
\hline
\end{tabular}




\begin{tabular}{|c|c|c|c|c|}
\hline 10. & Memberi evaluasi di akhir pembelajaran & 2 & 3 & 3 \\
\hline & Jumlah Skor & $\mathbf{2 2}$ & $\mathbf{2 9}$ & $\mathbf{3 7}$ \\
\hline Persentase & $\mathbf{5 5 \%}$ & $\mathbf{7 3 \%}$ & $\mathbf{9 3 \%}$ \\
\hline Kategori & $\mathbf{C}$ & $\mathbf{B}$ & $\mathbf{S B}$ \\
\hline
\end{tabular}

Pada siklus I keterampilan guru mendapatkan skor 22 dengan persentase 55\% termasuk kategori cukup, siklus II skor 29 dengan persentase 73\% termasuk kategori baik, siklus III skor 37 dengan persentase sebesar 93\% termasuk kategori sangat baik. Peningkatan keterampilan guru dapat dijabarkan sebagai berikut:

Melakukan pengkondisian awal kelas pada siklus I, II, III memperoleh skor 4 dengan 4 deskriptor yang tampak: a) mengkondisikan siswa untuk siap mengikuti pelajaran; b) menyiapkan alat peraga dan media pembelajaran dengan cermat dan teliti; c) mempersiapkan siswa secara fisik dan mental; d) melakukan pendekatan dengan komunikasi yang baik untuk menarik perhatian siswa.Membuka pelajaran pada siklus I memperoleh skor 2 dengan 2 deskriptor yang tampak: a) Memberikan apresiasi yang berkaitan dengan materi yang diajarkan; b) menyampaikan tujuan pembelajaran atau cakupan materi dengan kalimat yang jelas. Siklus II memperoleh skor 3 dengan 3 deskriptor yang tanpak: a) memberikan apersepsi yang berkaitan dengan materi yang diajarkan; b) memberikan gambaran sekilas tentang kegiatan pembelajaran yang akan dilaksanakan; c) menyampaikan tujuan pembelajaran atau cakupan materi dengan kalimat yang jelas. Siklus III memperoleh skor 4 dengan 4 deskriptor yang tampak: a) memberikan apersepsi yang berkaitan dengan materi yang diajarkan; b) memberikan gambaran sekilas tentang kegiatan pembelajaran yang akan dilaksanakan; c) menyampaikan tujuan pembelajaran atau cakupan materi dengan kalimat yang jelas; d) memberi motivasi kepada siswa untuk semangat dan tertib dalam mengikuti pembelajaran.Menyampaikan materi pelajaran pada siklus I memperoleh skor 2 dengan 2 deskriptor yang tampak: a) penjelasan menggunakan bahasa yang mudah dipahami; b) penyampaikan materi pelajaraan secara sistematis. Siklus II memperoleh skor 3 dengan 3 deskriptor yang tampak: a) penjelasan menggunakan bahasa yang mudah dipahami; b) menggunakan variasi suara dalam menjelaskan; c) menyampaikan materi pelajaraan secara sistematis. Siklus III memperoleh skor 4 dengan 4 deskriptor yang tampak: a) penjelasan menggunakan bahasa yang mudah dipahami; b) menggunakan variasi suara dalam menjelaskan; c) menyampaikan materi pelajaraan secara sistematis; d) memberi kesempatan bertanya pada siswa mengenai materi yang sedang dijelaskan.Mengajukan pertanyaan kepada siswa pada siklus I memperoleh skor 2 dengan 2 deskriptor yang tampak: a) pertanyaan jelas dan mudah dipahami siswa; b) memberi tanggapan yang positif terhadap jawaban siswa. Siklus II memperoleh skor 3 dengan 3 deskriptor yang tampak: a) pertanyaan jelas dan mudah dipahami siswa; b) memberi tanggapan yang positif terhadap jawaban siswa; c) memindahkan giliran menjawab kepada siswa lain. Siklus III memperoleh skor 4 dengan 4 deskriptor yang tampak: a) pertanyaan jelas dan mudah dipahami siswa; b) memberi tanggapan yang positif 
terhadap jawaban siswa; c) memindahkan giliran menjawab kepada siswa lain; d) memberi waktu untuk berpikir.Memberikan LKS berupa crossword puzzle pada siklus I memperoleh skor 2 dengan 2 deskriptor yang tampak: a) membagikan LKS kepada setiap kelompok; b) mampu memunculkan antusias siswa dalam mengerjakan. Siklus II memperoleh skor 3 dengan 3 deskriptor yang tampak: a) pertanyaan singkat dan jelas; b) membagikan LKS kepada setiap kelompok; c) mampu memunculkan antusias siswa dalam mengerjakan. Siklus III memperoleh skor 4 dengan 4 deskriptor yang tampak: a) pertanyaan singkat dan jelas; b) membagikan LKS kepada setiap kelompok; c) memberikan waktu yang cukup untuk mengerjakan; d) mampu memunculkan antusias siswa dalam mengerjakan.Memberi penguatan kepada kelompok yang menyelesaikan tugas dengan benar pada siklus I, II memperoleh skor 3 dengan 3 deskriptor yang tampak: a) guru memberikan penguatan secara nonverbal; b) guru memberikan respon secara verbal; c) guru memberikan respon sesegera mungkin setelah perilaku siswa yang diharapkan muncul. Siklus III memperoleh skor 4 dengan 4 deskriptor yang tampak: a) guru memberikan penguatan secara nonverbal; b) guru memberikan respon secara verbal; c) guru memberikan penguatan secara individual dan kelompok; d) guru memberikan respon sesegera mungkin setelah perilaku siswa yang diharapkan muncul.Membimbing dalam pembuatan concept mapping pada siklus I memperoleh skor 2 dengan 2 deskriptor yang tampak: a) menggambarkan contoh concept mapping di papan tulis; b) mengarahkan siswa menemukan konsep umum dan konsep khusus. Siklus II memperoleh skor 3 dengan 3 deskriptor yang tampak: a) menggambarkan contoh concept mapping di papan tulis; b) mengarahkan siswa menemukan konsep umum dan konsep khusus; c) membimbing siswa menempatkan konsep dari umum ke khusus dengan sabar dan bertanggung jawab. Siklus III memperoleh skor 4 dengan 4 deskriptor yang tampak: a) menggambarkan contoh concept mapping di papan tulis; b) mengarahkan siswa menemukan konsep umum dan konsep khusus c) membimbing siswa menempatkan konsep dari umum ke khusus dengan sabar dan bertanggung jawab; d) membimbing siswa membuat hubungan antar konsep dengan teliti dan jelas. Membimbing siswa dalam kelompok pada siklus I memperoleh skor 2 dengan 2 deskriptor yang tampak: a) memusatkan perhatian kepada setiap kelompok; b) berkeliling memberikan perhatian pada tiap kelompok. Siklus II memperoleh skor 3 dengan 3 deskriptor yang tampak: a) memusatkan perhatian kepada setiap kelompok; b) melakukan bimbingan pada setiap kelompok; c) berkeliling memberikan perhatian pada tiap kelompok. Siklus III memperoleh skor 4 dengan 4 deskriptor yang tampak: a) memusatkan perhatian kepada setiap kelompok; b) melakukan bimbingan pada setiap kelompok; c) memperjelas tugas yang harus dilakukan siswa; d) berkeliling memberikan perhatian pada tiap kelompok.Membimbing siswa menyimpulkan materi pada siklus I memperoleh skor 1 karena tidak ada deskriptor yang tampak. Siklus II memperoleh skor 1 dengan 1 deskriptor yang tampak: a) membantu siswa mengingat kembali materi yang baru saja dipelajari. Siklus III memperoleh skor 2 dengan 2 deskriptor yang tampak: a) membantu siswa mengingat kembali materi yang baru saja dipelajari; b) 
memberikan kesempatan kepada siswa untuk bertanya.Memberi evaluasi di akhir pembelajaran pada siklus I memperoleh skor 2 dengan 2 deskriptor yang tampak: a) memotivasi siswa untuk mengerjakan soal evaluasi secara mandiri; b) berkeliling memantau siswa mengerjakan evaluasi. Siklus II memproleh skor 3 dengan 3 deskriptor yang tampak: a) memotivasi siswa untuk mengerjakan soal evaluasi secara mandiri; b) berkeliling memantau siswa mengerjakan evaluasi; c) evaluasi diadakan sesuai dengan alokasi waktu yang disediakan.

Rusman (2012 : 68) menyebutkan bahwa keterampilan dasar mengajar guru secara aplikatif indikatornya dapat digambarkan melalui sembilan keterampilan mengajar. Keterampilan mengajar yang dimaksud adalah sebagai berikut: 1) keterampilan membuka pelajaran; 2) keterampilan bertanya; 3) keterampilan memberi penguatan; 4) keterampilan mengadakan variasi; 5) keterampilan menjelaskan; 6) keterampilan membimbing diskusi kelompok kecil; 7) keterampilan mengelola kelas; 8) keterampilan mengajar kelompok kecil dan perorangan; 9) keterampilan menutup pelajaran. Oleh karena itu, dengan skor yang diperoleh pada siklus terakhir maka peneliti sebagai guru kiranya dapat dikriteriakan sebagai guru yang efektif. Kauchak dan Eggen (1993:98) menjelaskan kriteria guru yang efektif adalah : 1) menuntut siswanya perprestasi tinggi, 2) sebagai model untuk tingkah laku tertentu, 3) dalam mengajar antusias, 4) responsif terhadap siswanya, 5) menggunakan bahasa yang jelas, 6) menghubungkan logika dengan presentasi, 7) dalam mengajar tahap-tahapnya jelas, 8) penekanan pada hal yang penting, 9) dalam berkomunikasi ada kesesuaian antara kata dan perbuatan, 10) tepat waktu, 11) menggunakan pengetahuan awal siswa, 12) mempunyai tanggung jawab yang tinggi.

\section{Aktivitas Siswa}

Peningkatan aktivitas siswa dalam pembelajaran IPA dapat dilihat pada tabel berikut:

Tabel 2 Peningkatan Aktivitas Siswa pada Siklus I, Siklus II, dan Siklus III

\begin{tabular}{|c|c|c|c|c|}
\hline No. & Indikator Aktivitas Siswa & Siklus I & Siklus II & Siklus III \\
\hline 1. & $\begin{array}{l}\text { Kesiapan siswa dalam mengikuti } \\
\text { pelajaran }\end{array}$ & 2,12 & 3,12 & 4 \\
\hline 2. & Menyimak penjelasan guru & 1,51 & 2,51 & 3,09 \\
\hline 3. & $\begin{array}{l}\text { Keaktifan siswa menjawab } \\
\text { pertanyaan }\end{array}$ & 1,54 & 2,54 & 3,42 \\
\hline 4. & Aktif mengajukan pertanyaan & 1 & 2 & 2 \\
\hline 5. & $\begin{array}{l}\text { Mengerjakan LKS berupa crossword } \\
\text { puzzle }\end{array}$ & 2,66 & 3,66 & 4 \\
\hline 6. & Membuat concept mapping & 2,33 & 4 & 4 \\
\hline 7. & Bekerjasama dengan kelompok & 1,81 & 2,81 & 3,54 \\
\hline 8. & $\begin{array}{l}\text { Mempresentasikan hasil } \\
\text { pekerjaannya }\end{array}$ & 1,36 & 2,36 & 2,45 \\
\hline 9. & Menyimpulkan materi & 1 & 2 & 2,03 \\
\hline 10. & $\begin{array}{l}\text { Antusias dalam mengerjakan soal } \\
\text { evaluasi }\end{array}$ & 2,81 & 3,75 & 4 \\
\hline \multicolumn{2}{|c|}{ Jumlah rata-rata skor yang diperoleh } & 18,18 & 28,78 & 32,54 \\
\hline \multicolumn{2}{|c|}{ Persentase ketuntasan } & $\mathbf{4 5 , 4 5 \%}$ & $71,97 \%$ & $81,36 \%$ \\
\hline \multicolumn{2}{|r|}{ Kategori } & $\mathbf{C}$ & B & SB \\
\hline
\end{tabular}


Pada siklus I aktivitas siswa mendapatkan skor rata-rata 18,18 dengan persentase 45,45\% yang termasuk dalam kategori cukup, siklus II skor rata-rata yang didapat 28,78 dengan persentase 71,97\% yang termasuk dalam kategori baik, siklus III skor rata-rata 32,54 dengan persentase 81,36\% yang termasuk dalam kategori sangat baik. Peningkatan aktivitas siswa dapat dijabarkan sebagai berikut:

Kesiapan siswa dalam mengikuti pelajaran pada siklus I memperoleh rerata skor 2,12 dengan kategori cukup, siklus II memperoleh rerata skor 3,12 dengan kategori baik, siklus III memperoleh rerata skor 4 dengan kategori sangat baik. Menyimak penjelasan guru pada siklus I memperoleh rerata skor 1,51 dengan kategori kurang, siklus II memperoleh rerata skor 2,51 dengan kategori cukup, siklus III memperoleh rerata skor 3,09 dengan kategori baik. Keaktifan siswa menjawab pertanyaan pada siklus I memperoleh rerata skor 1,54 dengan kategori kurang, siklus II memperoleh rerata skor 2,54 dengan kategori cukup, siklus III memperoleh rerata skor 3,42 dengan kategori baik. Aktif mengajukan pertanyaan pada siklus I memperoleh rerata skor 1 dengan kategori kurang, siklus II memperoleh rerata skor 2 dengan kategori cukup, siklus III memperoleh rerata skor 2 dengan kategori cukup.

Mengerjakan LKS berupa crossword puzzle pada siklus I memperoleh rerata skor 2,66 dengan kategori cukup, siklus II memperoleh rerata skor 3,66 dengan kategori baik, siklus III memperoleh rerata skor 4 dengan kategori sangat baik. Membuat concept mapping pada siklus I memperoleh rerata skor 2,33 dengan kategori cukup, siklus II memperoleh rerata skor 4 dengan kategori sangat baik, siklus III memperoleh rerata skor 4 dengan kategori sangat baik. Bekerjasama dengan kelompok pada siklus I memperoleh rerata skor 1,81 dengan kategori kurang, siklus II memperoleh rerata skor 2,81 dengan kategori cukup, siklus III memperoleh rerata skor 3,54 dengan kategori baik. Mempresentasikan hasil pekerjaannya pada siklus I memperoleh rerata skor 1,36 dengan kategori kurang, siklus II memperoleh rerata skor 2,36 dengan kategori cukup, siklus III memperoleh rerata skor 2,45 dengan kategori baik. Menyimpulkan materi pada siklus I memperoleh rerata skor 1 dengan kategori kurang, siklus II memperoleh rerata skor 2 dengan kategori cukup, siklus III memperoleh rerata skor 2,03 dengan kategori cukup. Antusias dalam mengerjakan soal evaluasi pada siklus I memperoleh rerata skor 2,81 dengan kategori cukup, siklus II memperoleh rerata skor 3,75 dengan kategori baik, siklus III memperoleh rerata skor 4 dengan kategori sangat baik.

Menurut Diedrich (dalam Sardiman, 2012) aktivitas siswa meliputi:visual activities, oral activities, listening activities, writing activities, drawing activities, motor activities, mental activities danemotion activities. Oleh karena itu, dengan skor yang diperoleh pada siklus terakhir maka aktivitas siswa telah dapat dicapai peningkatan aktivitas yang sangat signifikan. Hal ini sesuai dengan hasil pengamatan keterampilan guru yang juga mengalami peningkatan yang sangat signifikan pada semua aspek pengamatan. 


\section{Hasil Belajar Siswa}

Peningkatan hasil belajar dalam pembelajaran IPA dapat dilihat pada tabel berikut:

Tabel 3 Peningkatan Hasil Belajar pada Siklus I, Siklus II, dan Siklus III

\begin{tabular}{|c|l|c|c|c|}
\hline No. & \multicolumn{1}{|c|}{ Keterangan } & Siklus I & Siklus II & Siklus III \\
\hline 1. & Mean & 64,22 & 75,98 & 92,5 \\
\hline 2. & Median & 64,37 & 78 & 89,35 \\
\hline 3. & Modus & 62,56 & 80,21 & 95,5 \\
\hline 4. & Persentase Ketuntasan & $57,57 \%$ & $78,78 \%$ & $96,96 \%$ \\
\hline
\end{tabular}

Pada siklus I dapat dilihat mean 64,22, median 64,37, modus 62,56, dan persentase ketuntasan 57,57\% termasuk dalam kategori cukup. Pada siklus II mean 75,98, median 78, modus 80,21, dan persentase ketuntasan 78,78\% termasuk dalam kategori baik. Pada siklus III mean 92,5, median 89,35, modus 95,5, dan persentase ketuntasan 96,96\% termasuk dalam kategori sangat baik. Hasil belajar yang meningkat signifikan pada siklus terakhir ini adalah merupakan muara dari meningkatnya keterampilan guru dan aktivitas siswa pada semua aspek yang diamati.

Peningkatan hasil belajar juga disebabkan di samping sintaks concep mapping dan kelebihannya, peneliti juga mendesain pembelajaran berdasarkan teori dari Edgar Dale's Cone Experience.

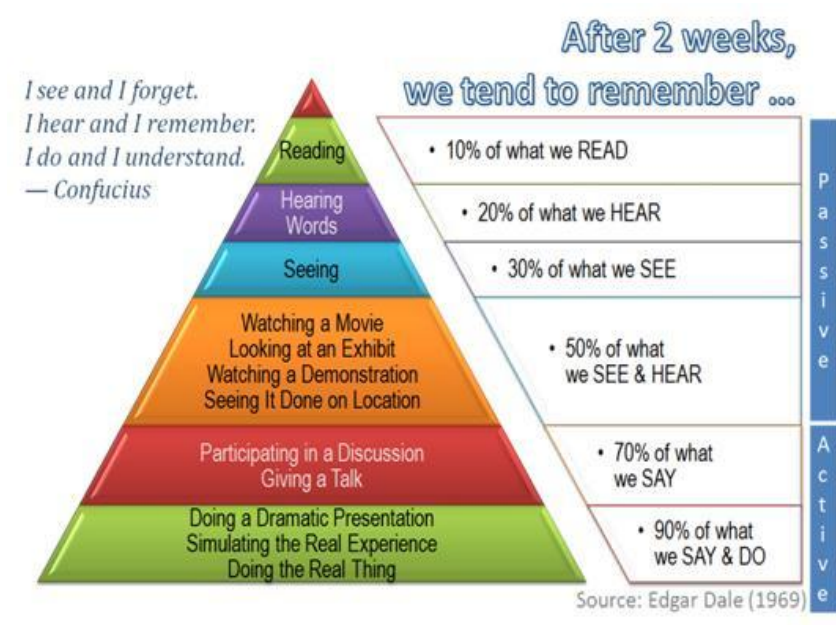

Semakin konkret siswa mempelajari bahan pengajaran, contohnya melalui pengalaman langsung, maka semakin banyak pengalaman yang diperoleh. Sebaliknya, semakin abstrak siswa memperoleh pengalaman, contohnya hanya mengandalkan bahasa verbal, maka semakin sedikit pengalaman yang akan diperoleh siswa (Sanjaya, 2008:165) 


\section{KESIMPULAN}

Berdasarkan hasil penelitian, disimpulkan bahwa conceptmapping dengan media gambar dapat meningkatkan keterampilan guru setiap siklusnya, siklus I memperoleh persentase 55\% dengan kategori cukup, siklus II memperoleh persentase $73 \%$ dengan kategori baik, siklus III memperoleh persentase 93\% dengan kategori sangat baik. Aktivitas siswa meningkat, yaitu siklus I memperoleh persentase 45,45\% kategori cukup, siklus II memperoleh persentase 71,97\% kategori cukup, dan siklus III memperoleh persentase 81,36 kategori baik. Hasil belajar meningkat, yaitu siklus I mencapai ketuntasan belajar klasikal 57,57\%, siklus II mencapai ketuntasan belajar klasikal 78,78\%, dan siklus III mencapai ketuntasan belajar klasikal 96,96\%.

Dari simpulan di atas, dapat diketahui bahwa hipotesis tindakan dari penelitian ini telah terjawab, yaitu Penerapan Concept Mapping dengan Media Gambar dapat Meningkatkan Kualitas Pembelajaran IPA Pada Siswa Kelas VB SDN 01 Sampangan Semarang. 


\section{DAFTAR PUSTAKA}

Arikunto, Suharsimi. 2008. Penelitian tindakan kelas. Jakarta: Bumi Aksara.

Aqib, Zainal, dkk. 2011. Penelitian tindakan kelas untuk guru SD, SLB dan TK. Bandung: Yrama Widya.

BSNP. 2006. Standar isi untuk satuan pendidikan dasar dan menengah standar kompetensi dan kompetensi dasar SD/MI. Jakarta: BSNP.

Dahar, Ratna Wilis. 2011. Teori-teori belajar dan pembelajaran. Jakarta: Erlangga.

Herrhyanto, Nar, dan H.M. Akib Hamid. 2008. Statistika dasar. Jakarta: Universitas Terbuka.

Kauchak dan Eggen, Donald P. 1993. Learning and Teaching: Research Based Methods. Second Edition. Needham Heights; Allyn and Bacon.

Munthe, Bermawi. 2014. Desain pembelajaran. Yogyakarta: Pustaka Insan Madani.

Poerwanti, Endang, dkk. 2008. Asesmen pembelajaran. Jakarta: Direktorat Jenderal Pendidikan Tinggi Departemen Pendidikan Nasional.

Rusman. 2012. Model-model pembelajaran: mengembangkan profesionalisme guru. Jakarta: Rajawali Pers.

Sardiman. 2012. Interaksi \& motivasi belajar mengajar. Jakarta: Rajawali Pers.

Sanjaya, Wina. 2008. Pembelajaran Dalam Implementasi Kurikulum Berbasis Kompetensi. Jakarta 